
37 Peremohy Ave., UA-03056 Kyiv, Ukraine

\title{
FABRICATION OF NANOSIZE FILMS ON THE BASE OF SCUTHERUDHTE COSb FOR THERMOELECTRIC DEVICES
}

The work is concerned with ascertainment of the regularities for thermostimulated formation of the phase composition and structure of $\mathrm{CoSb}_{3}$-scutterudite-based films deposited by the vacuum condensation method as well as the effect of the nanoscale factor on their thermoelectric properties. The influence of the substrate temperature and physical-technological parameters of heat treatment (temperature, duration, environment) on the phase composition, structure, mechanical-stress level, and thermoelectric properties of the $\mathrm{CoSb}_{x}(30 \mathrm{~nm})(1.8 \leq x \leq 4.2)(65-81$ at. $\% \mathrm{Sb})$ films is studied. As determined, the change in the substrate temperature during the deposition of nanoscale $\mathrm{Co}-\mathrm{Sb}$ films in the concentration range of $65-81$ at.\% $\mathrm{Sb}$ allows regulating the structural state. During the deposition on substrates at a room temperature, an X-ray amorphous state with an extended region for existence of the $\mathrm{CoSb}_{3}$-type phase at 75-80 at.\% $\mathrm{Sb}$ after crystallization and further heating is formed. When the substrate temperature increases up to $200{ }^{\circ} \mathrm{C}$, a crystalline state forms, and regularities of phase composition formation in $\mathrm{Co}-\mathrm{Sb}$ films are characterized by a sequence, which is analogous to the phase equilibrium diagram for the bulk state of the $\mathrm{Co}-\mathrm{Sb}$ system with the $\mathrm{CoSb}_{3}$-type phase formation at $\approx 75$ at. $\% \mathrm{Sb}$. As found, films based on $\mathrm{CoSb}_{3}$ are thermally stable up to $\approx 300{ }^{\circ} \mathrm{C}$. Thermal treatment of $\mathrm{Co}-\mathrm{Sb}$ films with an $\mathrm{Sb}$ concentration of $65-81$ at.\%, both in vacuum and under nitrogen, at the temperatures above $300{ }^{\circ} \mathrm{C}$, leads to the occurrence of phase transformations and a change in the structure according to the schemes: $\mathrm{CoSb}_{3}+\mathrm{Sb} \rightarrow \mathrm{CoSb}_{3}$ (at $300{ }^{\circ} \mathrm{C}$ ), $\mathrm{CoSb}_{3} \rightarrow \mathrm{CoSb}_{3}+\mathrm{CoSb}_{2}$ (at $400-500{ }^{\circ} \mathrm{C}$ ), $\mathrm{CoSb}_{2} \rightarrow$ $\rightarrow \mathrm{CoSb}_{2}+\mathrm{CoSb}$ (at 500-600 ${ }^{\circ} \mathrm{C}$ ) because $\mathrm{Sb}$ atoms get rise in an ability to sublimate from the X-ray amorphous or crystalline states and cobalt antimonides, $\mathrm{CoSb}_{2}$ and $\mathrm{CoSb}_{3}$, if annealing temperature increases. As determined, the presence of the nanoscale factor (i.e., the single-phase crystalline structure of $\mathrm{CoSb}_{3}$ scutterudite with an extended area of existence in the film form with increased structural imperfection due to the sublimation of antimony and reduction in the grain size) causes an increase in the thermoelectric efficiency coefficient of $\mathrm{Co}-\mathrm{Sb}$ films in $\approx 8$ times as compared to the bulk material. This has a practical importance when these materials 
are used for providing the autonomous power supply for low-power electronic devices and creating film coolers in the elemental base of the nanoscale range for computer equipment and infrared sensors.

Keywords: nanoscale film, heat treatment, $\mathrm{CoSb}_{3}$ scutterudite, antimonide, thermoelectric efficiency coefficient.

\section{Introduction}

Energy saving is an important component for the economic development of countries. Most of the electric power is produced via the thermal machines with a low efficiency factor (less than 40\%). That is more than half of the energy dissipates as a heat for nothing. That is why the thermoelectricity based on the Seebeck (direct conversion of thermal energy into electrical one) and Peltier (reverse thermoelectric cooling) effects is one of the priority trends in development of science and technology.

The efficiency of conversion of heat into electricity depends on the properties of a material and defined by the dimensionless value $Z T-$ thermoelectricity efficiency coefficient proposed by A.F. Ioffe. The $Z T$ parameter can be calculated with the formula $Z T=S^{2} T \sigma / k$, where $S$ is the Seebeck coefficient, $\sigma$ is an electrical conductivity, $T$ is a temperature, $k=k_{\mathrm{el}}+k_{\mathrm{ph}}$ is a total thermal conductivity coefficient ( $k_{\mathrm{el}}$ and $k_{\mathrm{ph}}$ are electron and phonon components of thermal conductivity) [1, 2]. Modern traditional materials $\left(\mathrm{Bi}_{2} \mathrm{Te}_{3}, \mathrm{PbTe}, \mathrm{Pb}_{x} \mathrm{Sn}_{1-x} \mathrm{Te}\right)$ possess a relatively low thermoelectricity efficiency coefficient $Z T \approx 0.6[3,4]$.

The problems arising in the search for new more efficient thermoelectric materials are caused by the fact that such a material must have simultaneously high electrical conductivity and low thermal conductivity. These two characteristics commonly accompany each other and their independent change remained practically unrealizable for a long time. A new trend in the search for thermoelectric materials arose in 1995, when G. Slack proposed a theory called as 'the concept of Phonon-Glass Electron-Crystals'. This is a group of special materials that can well conduct electrical energy (as a crystalline conductor) and poorly conduct thermal energy (like a glass), such as $M e-\mathrm{Sb}$ antimonides and $M e-\mathrm{As}$ arsenides, where $\mathrm{Me}$ is $\mathrm{Co}, \mathrm{Ir}, \mathrm{Rh}, \mathrm{Ni}$. Thus, a possibility to increase the energy factor $S^{2} T \sigma$, while decreasing the thermal conductivity $k$, appears [5].

Currently, the most promising material is a cobalt antimonide $\mathrm{CoSb}_{3}$ (scutterudite). In so doing, one of the ways to increase the thermoelectric efficiency coefficient of $\mathrm{CoSb}_{3}$ scutterudite is associated with application of nanoscale materials, such as nanofilms. According to theoretical calculations, the conversion to nanoscale materials makes it possible to increase $Z T$ up to several times due to a decrease in the thermal conductivity as a result of an increase in phonon scattering by the structural defectsgrain and layer boundaries that can be of nanoscale size [6-8]. 
Nowadays, the topical material science problems in the field of thermoelectricity are as follows. First, it is the creation of new materials, including nanomaterials with $Z T>1$ at high operating temperatures. Second, it is the establishment of a connection between the phase composition, structure, properties, functional stability and operational reliability during the conversion to nanoscale materials to enhance competitiveness with other methods of generating electricity. In this case, heat treatment is a key technological operation in the creation of a new functional material with high thermoelectric properties and performance characteristics. In addition, there are practically no studies on the formation of $\mathrm{CoSb}_{3}$ scutterudite-based films by the physical deposition methods.

The goal of the paper is to ascertain the behaviour characteristics for the processes of thermally stimulated formation of the phase composition and structure in the $30 \mathrm{~nm} \mathrm{CoSb}{ }_{x}$ films $(1.8 \leq x \leq 4.2$; $\mathrm{Sb}$ concentration belongs to the range of $65-81$ at. $\%$ ) obtained by molecular beam deposition on a $\mathrm{SiO}_{2}$ substrate $(100 \mathrm{~nm}) / \mathrm{Si}(001)$.

\section{Experimental Part}

The samples for the study were obtained at the Department of Surface Physics and Interfaces on the MBSI equipment of SGC600 series due to the cooperation within the framework of international DAAD projects according to L. Euler programs (ID No. 08/01145 in 2008-2009 and No. 50744282 in 2010-2011). Measurements of thermoelectric parameters were carried out by our German partner side $[9,10]$.

The $\mathrm{CoSb}_{x}(1.8 \leq x \leq 4.2)(65-81$ at.\% $\mathrm{Sb})$ films with thickness of $30 \mathrm{~nm}$ were obtained by molecular beam deposition under ultrahigh vacuum $\left(\approx 7 \cdot 10^{-9} \mathrm{~Pa}\right)$ on the substrates of single-crystal $\mathrm{Si}(001)$ with a $100 \mathrm{~nm}$ thick layer of $\mathrm{SiO}_{2}$ dioxide. An ultrahigh vacuum allowed elimination of the influence of the polluting atoms of the residual atmosphere $\left(\mathrm{N}_{2}, \mathrm{O}_{2}, \mathrm{Ar}\right.$, etc. $)$ on the phase composition and structure during deposition and heat treatment of nanoscale films. The presence of $\mathrm{SiO}_{2}$ oxide layer served as a barrier preventing the interdiffusion of the CoSb film with substrate silicon and silicide formations.

The substrate was rotated in order to reach the uniform deposition. The main physical and technological parameters, the change of which allows to obtain films with different phase composition and structure (crystalline and X-ray amorphous), were as follows: the deposition rate of elements, the substrate temperature, the medium, the temperature and the duration of their subsequent annealing. The substrate temperature $\left(T_{\mathrm{s}}\right)$ was either room temperature or $200{ }^{\circ} \mathrm{C}$. Antimony (Sb) was precipitated with an effusion (using a Knudsen cell) heated to the temperature of $470{ }^{\circ} \mathrm{C}$ at a constant rate of $0.3 \AA / \mathrm{s}$. Cobalt (Co) was vaporized by the 
electron beam method. The change in the chemical composition was achieved by varying the deposition rate Co in the range of 0.027 $0.049 \AA / \mathrm{s}$ at a constant deposition rate of $\mathrm{Sb}$. The deposition rate Co was measured with a vapour flow density sensor.

To calibrate the $\mathrm{Sb}$ deposition rate at different temperatures of substrate and obtain required thickness, the Rutherford backscattering (RBS) data were used. The film thickness was additionally controlled by $\mathrm{X}$-ray reflectometry along with quartz resonator. The statistical error value during measuring the film thickness was $\pm 1 \mathrm{~nm}$. After the precipitation, the samples were annealed in a vacuum or in a nitrogen atmosphere. Annealing of the samples was carried out on a VUP-5 equipment in a vacuum $\left(\approx 10^{-3} \mathrm{~Pa}\right)$ in the temperature range $100-700{ }^{\circ} \mathrm{C}$ with a holding time of $30 \mathrm{~s}, 0.5$ hour and 1 hour. Annealing in a nitrogen atmosphere was performed on a high-speed heat treatment unit AST SHS 10 within the temperature range $300-700{ }^{\circ} \mathrm{C}$ during 30 seconds. To determine the thermal stability of $\mathrm{Co}-\mathrm{Sb}$ films, the long-time annealing in a vacuum during $2-5$ hours was carried out.

To study the phase composition and structure of the films, we applied a set of methods of the physical materials science. They are X-ray diffraction phase analysis, the Debye-Scherrer method with photographic X-ray registration on the URS-55 equipment $\left(\lambda_{K \alpha}\right.$-Co radiation, exposure time up to 30 hours), survey on the DRON UM-1 diffractometer ( $\lambda_{K \alpha}-$ Fe radiation), and Rigaku Ultima IV ( $\lambda_{K \alpha}-\mathrm{Cu}$ radiation). The survey was performed for an angle range $2 \theta \in\left[10-80^{\circ}\right]$ with a step of $0.02^{\circ}$ and a waiting time of $2 \mathrm{~s}$ at one point. Measurements of the mechanical residual stresses in the samples were carried out using X-ray tensometrythe $\sin ^{2} \psi$ method by the diffraction reflex (310) of the $\mathrm{CoSb}_{3}$ phase. The average size of the coherent scattering regions (CSR) was calculated via the Debye-Scherrer formula. The chemical composition was determined by the Rutherford backscattering methods with an accuracy of \pm 1 at.\%, using $\mathrm{He}^{+}$ions accelerated by an energy of $1.7 \mathrm{MeV}$. The layer-by-layer chemical analysis was performed by the method of mass spectrometry of secondary neutrals (MSSN) on the Specs INA-X device. Electroconductivity properties were measured by a four-probe method. To study the morphology of the surface of nanosized films, we used both scanning electron microscopy (SEM, REMMA-106I) and atomic force microscopy (AFM, Dimension 3000). Two methods for determining the quantitative phase composition were used. The first one is the metallographic method of 'secants' using the Image-Pro Plus v.7.0 software based on the results of analysis of images obtained by the scanning electron microscopy. The second method is based on A.A. Rusakov's technique using the ratio of the intensities of the diffraction maxima on diffractograms for the films with a two-phase composition. 


\section{Results and Discussions}

The $\mathrm{CoSb}_{x}$ films (30 nm; $1.8 \leq x \leq 4.2 ; 65-81$ at.\% of $\mathrm{Sb}$ ) deposited on the substrate at room temperature are in the X-ray amorphous state since it is confirmed by X-ray diffraction analysis data, namely, there no diffraction maxima on the diffractograms (Fig. 1). The heating of $\mathrm{X}$-ray amorphous films in the temperature range of $\approx 140-200{ }^{\circ} \mathrm{C}$ results to their crystallization (Fig. 2).

The process of transformation into a crystal state in the $\mathrm{CoSb}_{x}$ $(2.6 \leq x \leq 4.1) 30 \mathrm{~nm}$ films is accompanied with an abrupt (jump) increase in electrical conductivity (Fig. $3, a, b$ ). As established using the

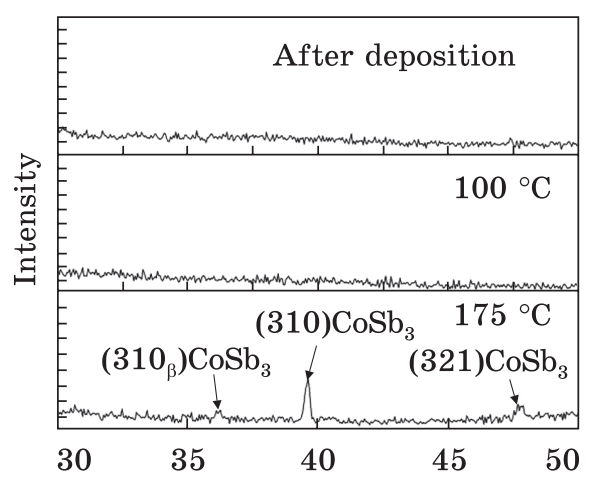

Diffraction angle $2 \Theta$, degree

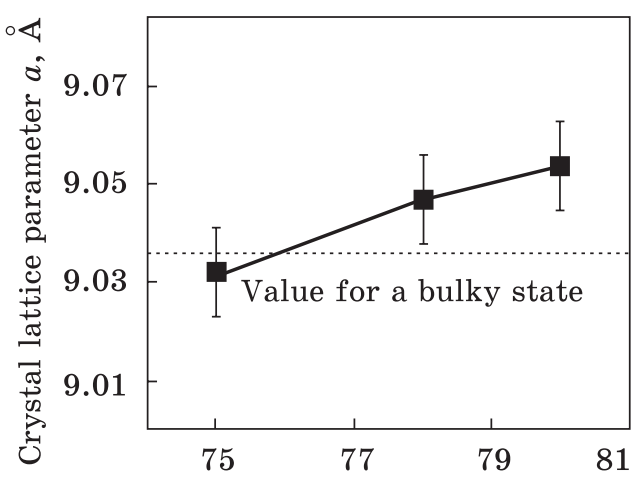

Content of antimony, at.\%

Fig. 1. X-ray patterns of as-deposited $\mathrm{CoSb}_{3.5}$ film on substrate at a room temperature and after heating $\left(\lambda_{K \alpha \beta}-\mathrm{Fe}\right)$

Fig. 2. Changing of a lattice parameter $a$ for $\mathrm{CoSb}_{3}$ phase after heating of $\mathrm{Co}-\mathrm{Sb}$ films up to $200{ }^{\circ} \mathrm{C}$
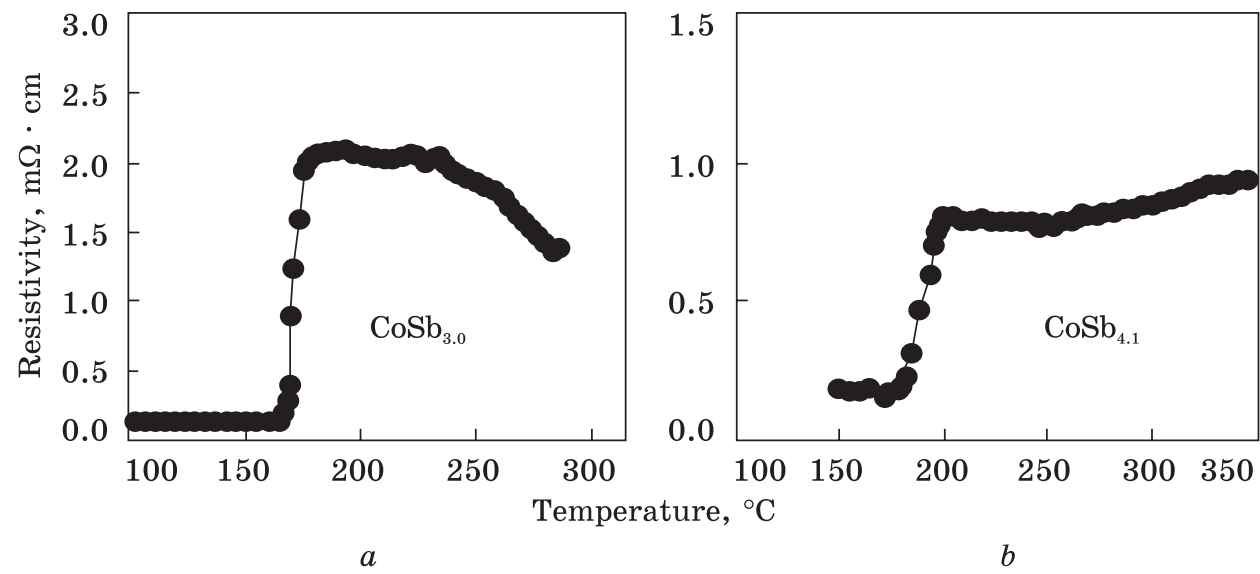

Fig. 3. Dependence of electrical resistance of $\operatorname{CoSb}_{3.0}(a)$ and $\operatorname{CoSb}_{4.1}(b)$ films on heating temperature (substrate temperature $T_{\mathrm{s}}=20{ }^{\circ} \mathrm{C}$ ) 


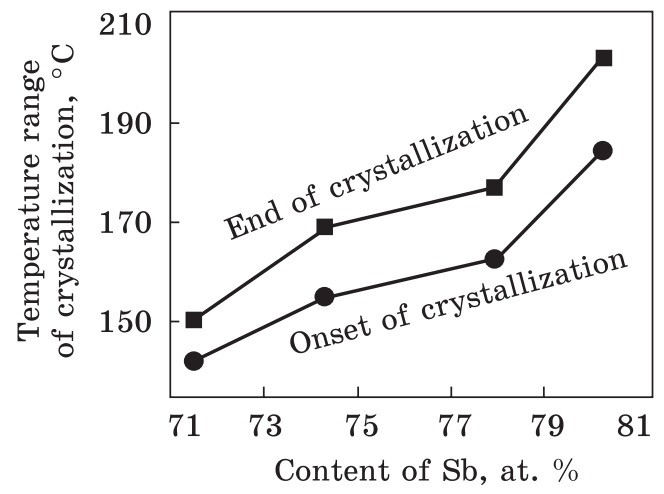

Fig. 4. Influence of $\mathrm{Sb}$ content on a crystallization range for $\mathrm{Co}-\mathrm{Sb}$ films
$\mathrm{X}$-ray structural phase analysis and resistometry, if the $\mathrm{Sb}$ concentration increases, the temperature range of crystallization of the investigated films shifts toward higher temperatures and amounts $140-200{ }^{\circ} \mathrm{C}$ (Fig. 4).

Electrophysical properties of the films depend on their chemical and phase compositions. Phase composition affects a temperature dependence of the resistivity $R=f(T)$. After crystallization from X-ray amorphous state in $\mathrm{CoSb}_{3.0}$ film, the dependence $R=f(T)$ has a semiconductor character with ionic conductivity type (Fig. 3, a). In $\mathrm{CoSb}_{3.5}$ film with an abundant Sb concentration (more than 75 at.\%), the temperature dependence of conductivity has a metallic behaviour (Fig. 3, b).

$\mathrm{X}$-ray structural phase analysis showed that after crystallization of $\mathrm{X}$-ray amorphous films, a single-phase composition corresponding to

Table 1. Phase composition after heating of X-ray amorphous $30 \mathrm{~nm}$ thick $\mathrm{CoSb}_{x}(2.4 \leq x \leq 4.1 ; 72-80$ at.\% Sb) films

\begin{tabular}{|c|c|c|c|c|}
\hline \multirow{2}{*}{$T,{ }^{\circ} \mathrm{C}$} & \multicolumn{4}{|c|}{ Concentration of $\mathrm{Sb}\left(c_{\mathrm{Sb}}\right)$ in the film, at. $\%$} \\
\hline & 72 & 75 & 78 & 80 \\
\hline \multicolumn{5}{|c|}{ Phase composition of nanosize $\mathrm{Co}-\mathrm{Sb}$ films after heating } \\
\hline 100 & \multicolumn{4}{|c|}{ X-ray amorphous state } \\
\hline 200 & \multicolumn{4}{|c|}{ Phase composition of $\mathrm{Co}-\mathrm{Sb}$ in a bulky state after heating } \\
\hline 200 & $\mathrm{CoSb}_{3}+\mathrm{CoSb}_{2}$ & $\mathrm{CoSb}_{3}$ & $\mathrm{CoSb}_{3}+\mathrm{Sb}$ & $\mathrm{CoSb}_{3}+\mathrm{Sb}$ \\
\hline
\end{tabular}

Table 2. Phase composition of the as-deposited $\mathrm{CoSb}_{x} 30 \mathrm{~nm}$ thick films, where $1.8 \leq x \leq 4.2(65-81$ at. $\%$ Sb)

\begin{tabular}{|r|c|c|c|c|c|c|c|}
\hline \multirow{2}{*}{$T_{\mathrm{s}},{ }^{\circ} \mathrm{C}$} & \multicolumn{7}{|c|}{ Concentration of $\mathrm{Sb}\left(c_{\mathrm{Sb}}\right)$ in the film, at.\% } \\
\cline { 2 - 7 } & 65 & 71 & 72 & 75 & 76 & 78 & 81 \\
\hline 20 & \multicolumn{7}{|c|}{$\begin{array}{c}\text { Phase state after as-deposition } \\
\text { X-ray amorphous state }\end{array}$} \\
200 & $\mathrm{CoSb}_{2}$ & $\begin{array}{c}\mathrm{CoSb}_{3}+ \\
+\mathrm{CoSb}_{2}\end{array}$ & $\begin{array}{c}\mathrm{CoSb}_{3}+ \\
+\mathrm{CoSb}_{2}\end{array}$ & $\mathrm{CoSb}_{3}$ & $\mathrm{CoSb}_{3}+\mathrm{Sb}$ & $\mathrm{CoSb}_{3}+\mathrm{Sb}$ & $\mathrm{CoSb}_{3}+\mathrm{Sb}$ \\
\hline
\end{tabular}




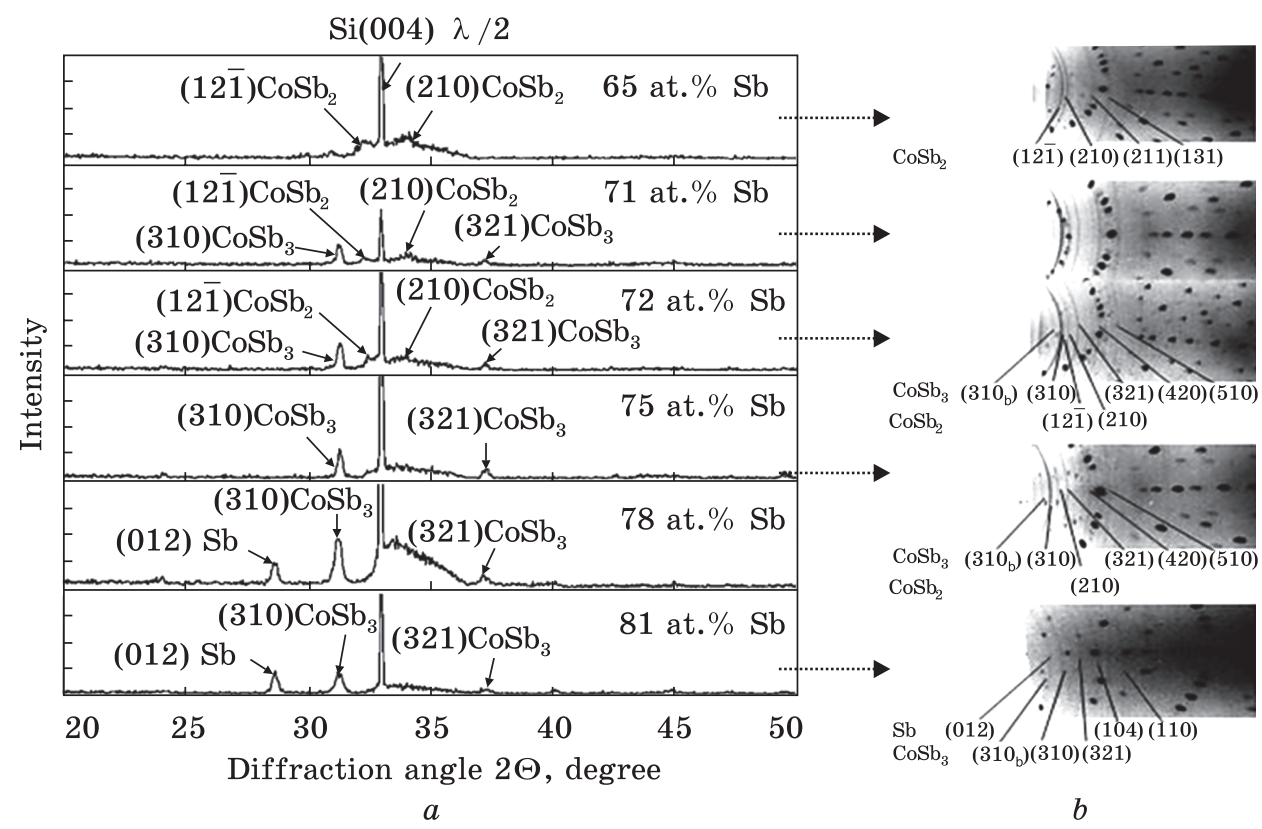

Fig. 5. X-ray diffraction $(a)$ and Debye powder $(b)$ patterns for Co-Sb films after deposition on $\mathrm{SiO}_{2}(100 \mathrm{~nm}) / \mathrm{Si}(001)$ substrates at $T_{\mathrm{s}}=200{ }^{\circ} \mathrm{C}$ (radiation: $\lambda_{K \alpha}-\mathrm{Cu}(a)$, $\left.\lambda_{K \alpha \beta}-\operatorname{Co}(b)\right)$

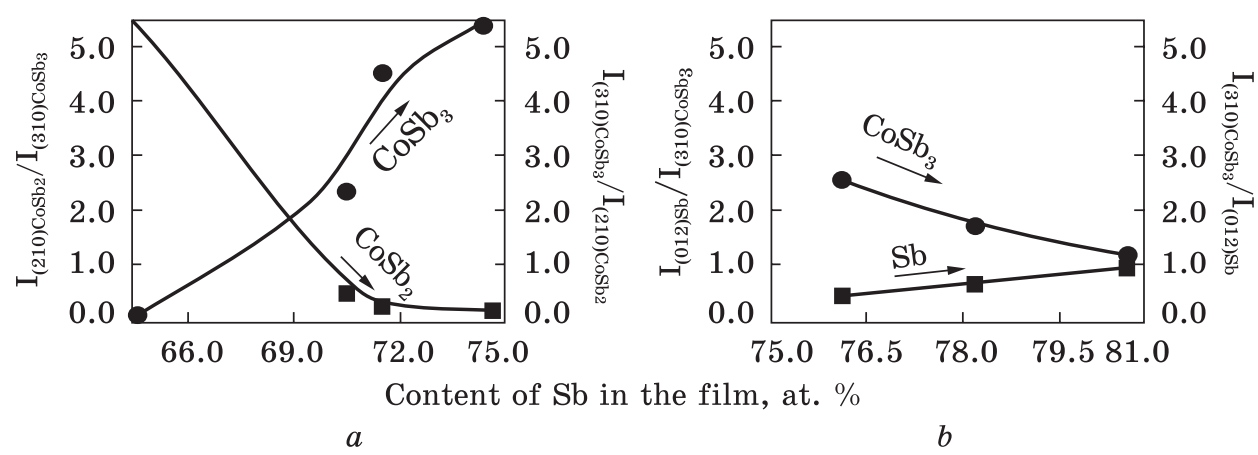

Fig. 6. A change in a ratio of diffraction reflection intensities as a function of $\mathrm{Sb}$ content: (a) $I(210) \mathrm{CoSb} / I(310) \mathrm{CoSb}_{3}$ and $I(310) \mathrm{CoSb}_{3} / I(210) \mathrm{CoSb}_{2}$ in the films with $c_{\mathrm{Sb}} \leq 75$ at.\%, (b) $I(012) \mathrm{Sb} / I(310) \mathrm{CoSb}_{3}$ and $I(310) \mathrm{CoSb}_{3} / I(012) \mathrm{Sb}$ in the films with $c_{\mathrm{Sb}}>75$ at. $\%$

$\mathrm{CoSb}_{3}$ scutterudite was observed in a wide concentration range of $75-$ 80 at. $\% \mathrm{Sb}$. The large values of the lattice parameter a for the $\mathrm{CoSb}_{3}$ phase as compared to those for a bulk state of the material indicate that atoms of abundant antimony occupy voids in the unite crystal cell (Fig. 2). These results indicate that region of existence of scutterudite $\mathrm{CoSb}_{3}(75-80$ at. $\% \mathrm{Sb}$ ) broadens by $5 \%$ (Table 1 ). 


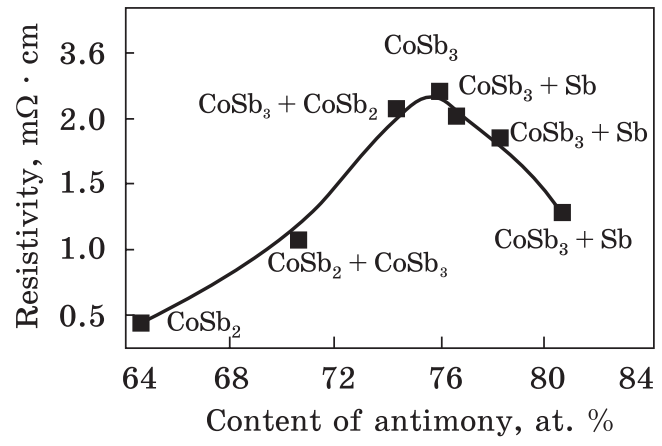

Fig. 7. Effect of antimony content on electrical resistance of $\mathrm{Co}-\mathrm{Sb}$ films

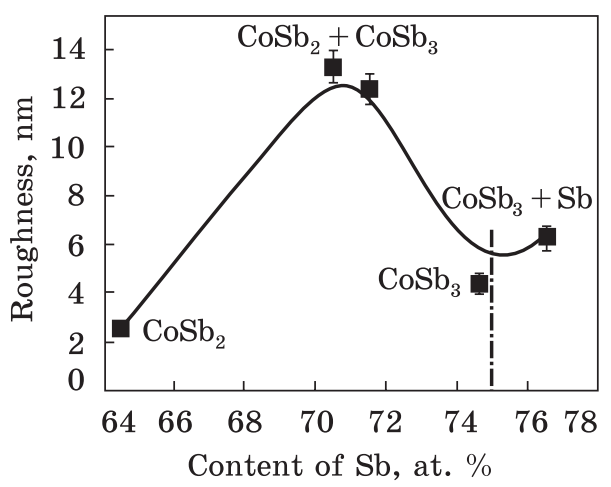

Fig. 8. Dependence of the roughness for $\mathrm{Co}-\mathrm{Sb}$ films on the $\mathrm{Sb}$ concentration

After deposition on a substrate at a temperature of 200 ${ }^{\circ} \mathrm{C}$, the $\mathrm{CoSb}_{x}(1.8 \leq x \leq 4.2)$ films had a crystal structure (Fig. 5). The diffraction maximum intensities for the films coincide with those values for the bulky material; this fact indicates that films are in a non-textured polycrystalline state. In the film containing 75 at. $\%$ $\mathrm{Sb}$, the scutterudite $\mathrm{CoSb}_{3}$ crystallizes during the deposition. In the films with Sb concentration less than 75 at. $\%$, the $\mathrm{CoSb}_{2}$ antimonide is formed additionally to the $\mathrm{CoSb}_{3}$. In the samples with abundant Sb concentration (more than 75 at.\%), two phases appear: $\mathrm{CoSb}_{3}$ and $\mathrm{Sb}$ (Fig. 5).

The decrease in the ratio of the diffraction maximum intensities $I(210) \mathrm{CoSb}_{2} / I(310) \mathrm{CoSb}_{3}$ in the films for a concentration range $c_{\mathrm{Sb}} \in$ [65 at. $\%, 75$ at. $\%$ ] indicates that $\mathrm{CoSb}_{3}$ phase increase (Fig. 6, a). While the change in the ration of the diffraction reflections $I(012) \mathrm{Sb} / I(310) \mathrm{CoSb}_{3}$ in the range 75 at. $\%<c_{\mathrm{Sb}} \leq 81$ at. $\%$ indicates that phase $\mathrm{CoSb}_{3}$ decreases as the $\mathrm{Sb}$ concentration increases (Fig. 6, b). This is also in agreement with results of quantity metallographic analysis of the patterns obtained via the SEM.

Thus, using the molecular-beam deposition method to vary the temperature, we can obtain X-ray amorphous (at $20^{\circ} \mathrm{C}$ ) and crystalline (at $200{ }^{\circ} \mathrm{C}$ ) states. The phase composition formation in the nanosized films deposited at $200{ }^{\circ} \mathrm{C}$ depends on the Sb content and occurs accordingly to the predictions in the equilibrium phase diagram for the bulky state of the Co-Sb system (Table 2).

The change in the phase composition of the films results to the change in the resistivity. The Sb-concentration-dependence of resistivity has a parabolic behaviour for the films with a maximum at 75 at. $\%$ of $\mathrm{Sb}$. The $\mathrm{CoSb}_{3}$ scutterudite is a more high-resistant phase as compared with both $\mathrm{CoSb}_{2}$ and $\mathrm{Sb}$ (Fig. 7). 


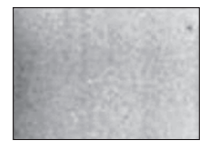

$\mathrm{CoSb}_{1.8}(30 \mathrm{~nm})$ $\mathrm{CoSb}_{2}$

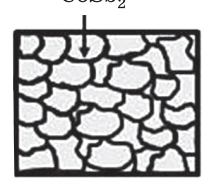

65 at. $\% \mathrm{Sb}$

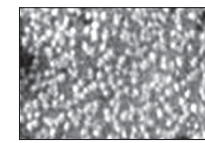

$\mathrm{CoSb}_{2.4}(30 \mathrm{~nm})$ $\mathrm{CoSb}_{2}+\mathrm{CoSb}_{3}$

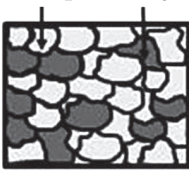

(75-4) at. $\% \mathrm{Sb}$

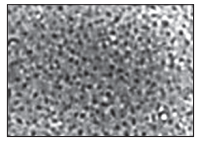

$\mathrm{CoSb}_{2.5}(30 \mathrm{~nm})$ $\mathrm{CoSb}_{3}+\mathrm{CoSb}_{2}$

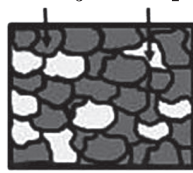

(75-3) at. $\% \mathrm{Sb}$

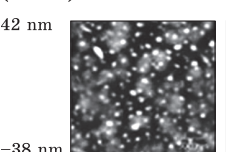

$\mathrm{CoSb}_{2.5}(30 \mathrm{~nm})$

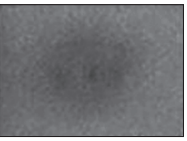

$\approx \mathrm{CoSb}_{3}(30 \mathrm{~nm})$ $\mathrm{CoSb}_{3}$

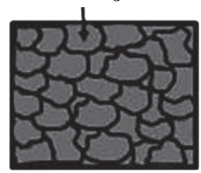

$\approx 75$ at. $\% \mathrm{Sb}$

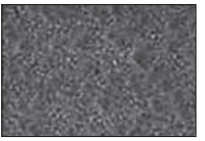

$\mathrm{CoSb}_{3.6}(30 \mathrm{~nm})$ $\mathrm{CoSb}_{3}+\mathrm{Sb}$

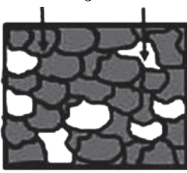

$(75+3)$ at. $\% \mathrm{Sb}$

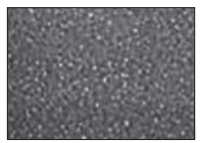

$\mathrm{CoSb}_{4.2}(30 \mathrm{~nm})$

$\mathrm{CoSb}_{3}+\mathrm{Sb}$

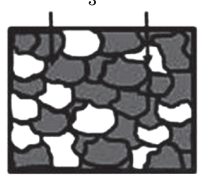

$(75+6)$ at. $\% \mathrm{Sb}$
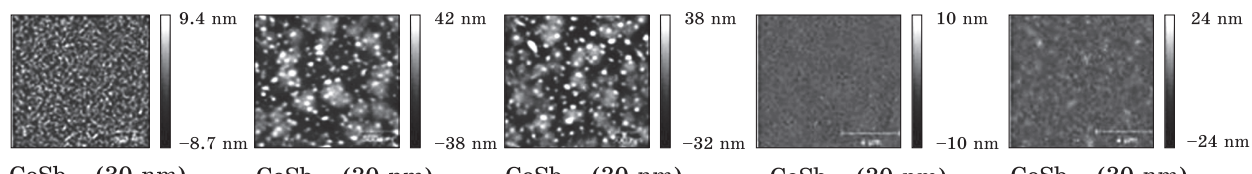

$\mathrm{CoSb}_{3.3}(30 \mathrm{~nm})$

Fig. 9. The morphology of the surface of $30 \mathrm{~nm}$ thick $\operatorname{CoSb}_{x}(1.8 \leq x \leq 4.2 ; 65-$ 81 at.\% Sb) films after deposition at $T_{\mathrm{s}}=200{ }^{\circ} \mathrm{C}$ : (above) surface images obtained by SEM; (in the middle) qualitative model concepts on the phase composition formation; (below) surface images obtained by AFM

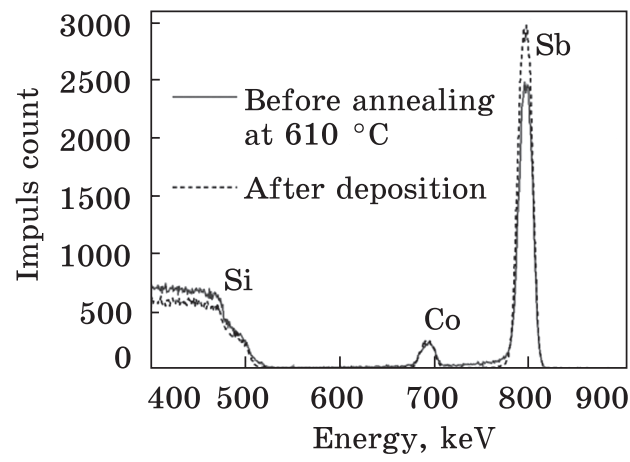

$a$

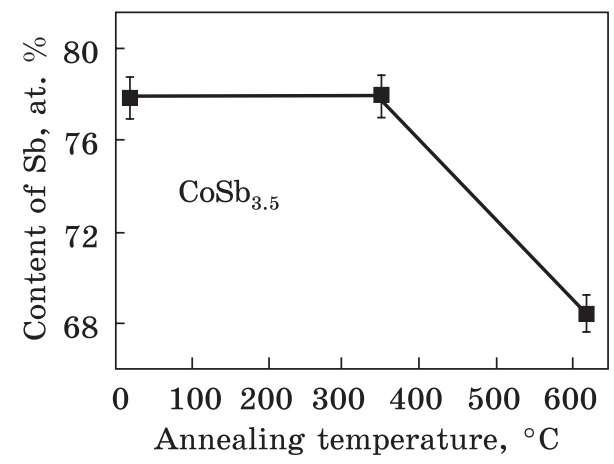

$b$

Fig. 10. Change of RBS spectra of $\mathrm{CoSb}_{3.6}$ film (78 at.\% Sb) after deposition at $T_{\mathrm{s}}=20{ }^{\circ} \mathrm{C}$ and annealing in vacuum $(a)$. Concentration of antimony as a function of annealing temperature $(b)$

Atomic force microscopy data demonstrate that a surface roughness of the films has a minimal value of $3-5 \mathrm{~nm}$ in the single-phase structures (Fig. 8). It contributes to the minimization of the resistivity and hence enhances a thermoelectric efficiency coefficient $Z T$.

Figure 9 exhibits the surface morphology for $30 \mathrm{~nm}$ thick films $\mathrm{CoSb}_{x}$ $(1.8 \leq x \leq 4.2 ; 65-81$ at. $\% \mathrm{Sb})$ and shows qualitative model of the phase state formation in the nanosized films deposited on a substrate at $200{ }^{\circ} \mathrm{C}$. One can easy see that in process of deposition, a scutterudite forms for 


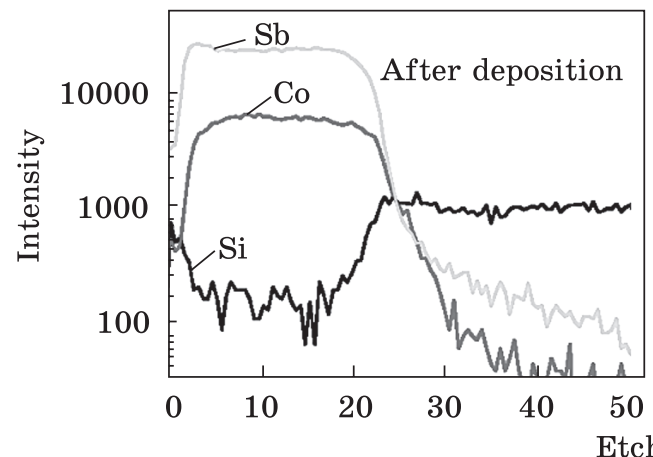

Etching time, $\mathrm{s}$

$a$

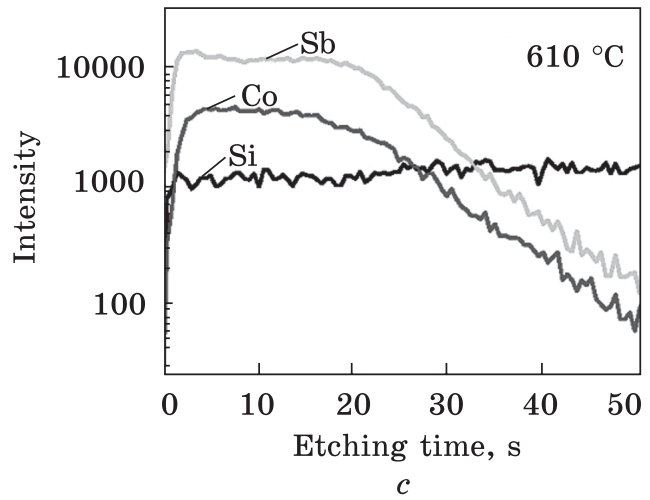

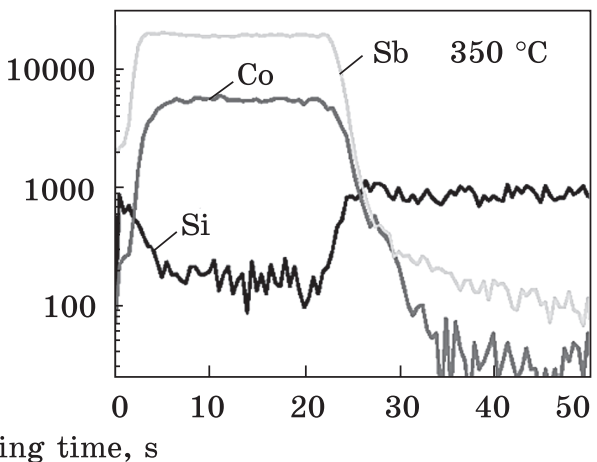

$b$

Fig. 11. The layer-by-layer distributions of elements in $\mathrm{CoSb}_{4.1}(30 \mathrm{~nm}) /$ $\mathrm{SiO}_{2}(100 \mathrm{~nm}) / \mathrm{Si}(001)$ after deposition and annealing in vacuum at $350{ }^{\circ} \mathrm{C}$ and $610{ }^{\circ} \mathrm{C}$

$\approx 75$ at. $\% \mathrm{Sb}$ (homogeneous system), while decrease or increase of antimony content leads to the formation of additional phases (heterogeneous system).

When the Sb-rich films $\mathrm{CoSb}_{3.6}$ and $\mathrm{CoSb}_{4.2}$ with a two-phase composition (scutterudite $\mathrm{CoSb}_{3}$ and crystalline antimony $\mathrm{Sb}$ ) are subjected to annealing in a vacuum above $500{ }^{\circ} \mathrm{C}$, the ratio of the intensities of the diffraction reflections $I$ (210) $\mathrm{Sb} / I(310) \mathrm{CoSb}_{3}$ decreases. The results of Rutherford backscattering show that content of antimony in the films decreases after annealing (Fig. 10). For instance, one can see on the RBS spectra in Fig. 10, $a$ that the intensity of the energy level for antimony decreases after annealing of the $\mathrm{CoSb}_{3.5}$ film in vacuum at $610{ }^{\circ} \mathrm{C}$ during $30 \mathrm{~s}$, and antimony concentration decreases by $\approx 10$ at.\% (Fig. 10, b). This is due to the sublimation of antimony during annealing.

We used a method of mass spectrometry of secondary neutrals for performing a layer-by-layer chemical analysis of atomic distribution over the thickness of $\mathrm{CoSb}_{4.1}(30 \mathrm{~nm}) / \mathrm{SiO}_{2}(100 \mathrm{~nm}) / \mathrm{Si}(001)$ sample. The obtained results showed that there is no the interdiffusion of the film and substrate atoms (Fig. 11, a). There is no also a formation of silicides. As the annealing temperature rises up to $610{ }^{\circ} \mathrm{C}$, the curves describing concentration distribution of elements show a reduction in the intensity attributed to antimony due to decrease of its concentration in the film (Fig. 11,c). 

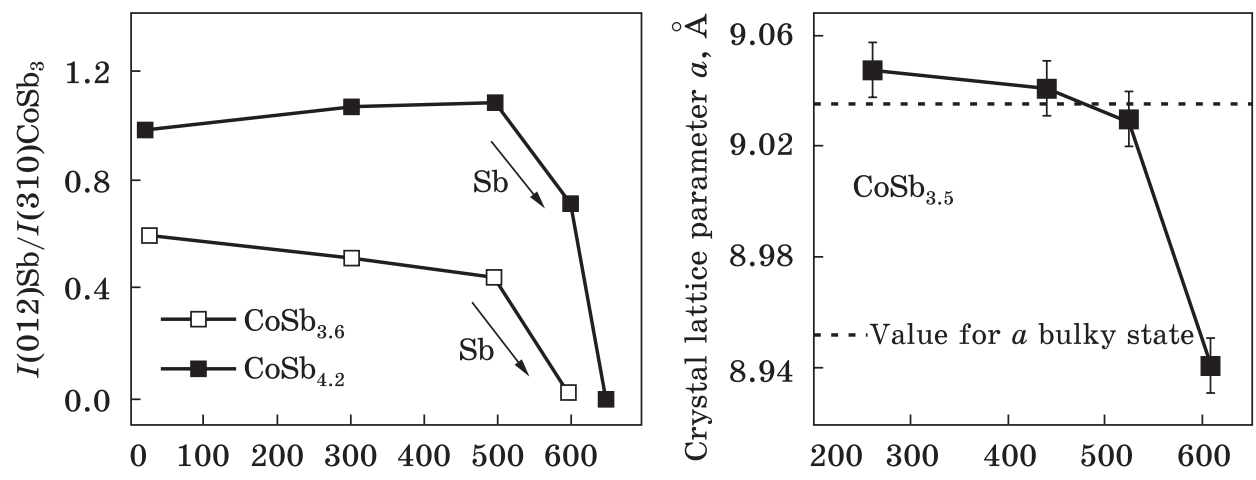

Annealing temperature, ${ }^{\circ} \mathrm{C}$

$a$

$b$

Fig. 12. Influence of annealing temperature for $\mathrm{CoSb}_{3.6}$ and $\mathrm{CoSb}_{4.2}$ films (in vacuum) on the change of $(a)$ ratio of intensities $I(012) \mathrm{Sb} / I(310) \mathrm{CoSb}_{3}$ of diffraction reflections and $(b)$ the lattice parameter a for $\mathrm{CoSb}_{3}$ phase

The emergence of a signal due to silicon is explained by the presence of voids with a depth reaching the substrate, i.e. voids occupy all thickness of the film [12]. A gradual atomization of material is a feature of the MSSN technique, therefore elements of the film surface and silicon substrate begin to produce a signal simultaneously during the chemical analysis (Fig. 11, c).

The annealing of films, where the concentration of $\mathrm{Sb}$ is close to its content in a scutterudite in vacuum above $300{ }^{\circ} \mathrm{C}$, results in the change of the phase composition. One can see the appearance of the $\mathrm{CoSb}_{2}$ reflexes in the diffraction pattern and growth of the intensity ratio $I$ (210) $\mathrm{CoSb}_{2} / I$ (310) $\mathrm{CoSb}_{3}$ in the absence of texture (Fig. 12, a). This indicates that $\mathrm{CoSb}_{2}$ phase grows, while $\mathrm{CoSb}_{3}$ one reduces. Therewith, the parameter $a$ of the cubic crystal lattice of scutterudite decreases (Fig. 12,b), and for the most part $a$ decreases in the films after crystallization from the X-ray-amorphous state.

Such a change in the phase composition is attributed to the partial sublimation of $\mathrm{Sb}$ atoms out of $\mathrm{CoSb}_{2}$ and $\mathrm{CoSb}_{3}$ crystal lattices during annealing in the nitrogen atmosphere as well as vacuum due to the phase transformations according to the schemes:

$$
\begin{gathered}
\mathrm{CoSb}_{3}+\mathrm{Sb} \stackrel{>300^{\circ} \mathrm{C}(\mathrm{Sb} \uparrow)}{\longrightarrow} \mathrm{CoSb}_{3} \stackrel{>400-500{ }^{\circ} \mathrm{C}(\mathrm{Sb} \uparrow)}{\longrightarrow} \mathrm{CoSb}_{3}+\mathrm{CoSb}_{2}, \\
\mathrm{CoSb}_{2} \stackrel{>500-600{ }^{\circ} \mathrm{C}(\mathrm{Sb} \uparrow)}{\longrightarrow} \mathrm{CoSb}_{2}+\mathrm{CoSb} .
\end{gathered}
$$

Detailed data about an effect of annealing conditions on the formation of phase composition and structure of nanosize $\mathrm{Co}-\mathrm{Sb}$ films are reported in our previous paper [11]. 

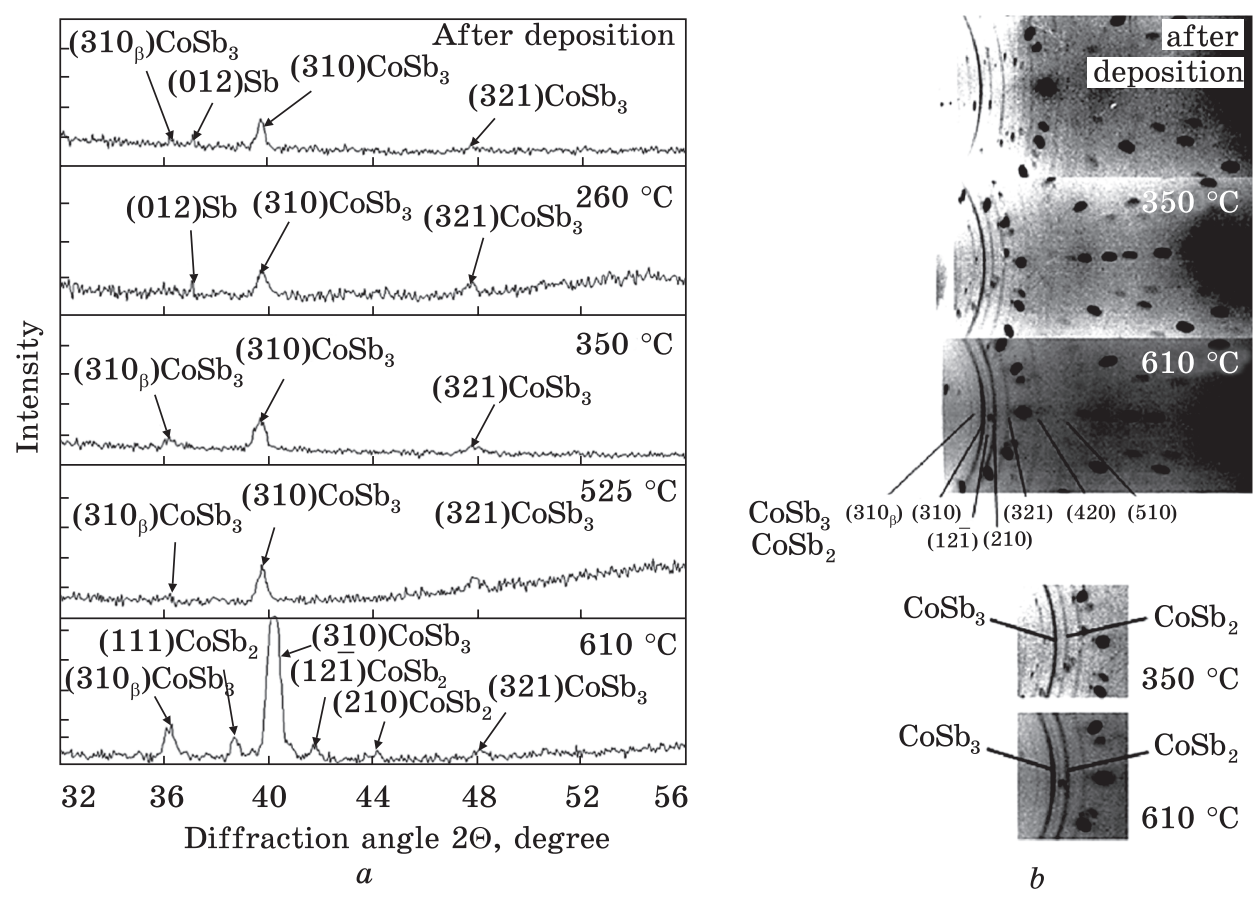

Fig. 13. X-ray diffraction patterns for $\mathrm{CoSb}_{3.3}(a)$ and Debye powder patterns for $\mathrm{CoSb}_{2.9}$ (b) $30 \mathrm{~nm}$ thick films after deposition on a substrate at $200{ }^{\circ} \mathrm{C}$ and annealing in vacuum within the temperature range of $260-610{ }^{\circ} \mathrm{C}\left(\lambda_{K \alpha \beta}-\mathrm{Fe}(a), \lambda_{K \alpha \beta}-\mathrm{Co}(b)\right)$

Table 3. Phase composition of thick $\mathrm{CoSb}_{x}$ films of $30 \mathbf{n m}$ (1.8 $\leq x \leq 4.2 ; 65-81$ at. $\% \mathrm{Sb})$ after annealing in the vacuum

\begin{tabular}{|c|c|c|c|c|c|c|c|}
\hline \multirow{2}{*}{$T,{ }^{\circ} \mathrm{C}$} & \multicolumn{7}{|c|}{ Concentration of antimony in the film $\left(c_{\mathrm{Sb}}\right)$, at. $\%$} \\
\hline & 65 & 71 & 72 & 75 & 76 & 78 & 81 \\
\hline & \multicolumn{7}{|c|}{ Phase composition after annealing } \\
\hline 300 & \multirow{5}{*}{$\begin{array}{l}\mathrm{CoSb}_{2}+ \\
+\mathrm{CoSb}\end{array}$} & \multirow{5}{*}{$\begin{array}{l}\mathrm{CoSb}_{3}+ \\
+\mathrm{CoSb}_{2} \\
\mathrm{CoSb}_{3}+ \\
+\mathrm{CoSb}_{2} \\
\mathrm{CoSb}_{3}+ \\
+\mathrm{CoSb}_{2}\end{array}$} & \multirow{5}{*}{$\begin{array}{l}\mathrm{CoSb}_{3}+ \\
+\mathrm{CoSb}_{2} \\
\mathrm{CoSb}_{3}+ \\
+\mathrm{CoSb}_{2} \\
\mathrm{CoSb}_{3}+ \\
+\mathrm{CoSb}_{2}\end{array}$} & \multirow{3}{*}{$\begin{array}{l}\mathrm{CoSb}_{3}+ \\
+\mathrm{CoSb}_{2}\end{array}$} & $\begin{array}{c}\mathrm{CoSb}_{3}+ \\
+\mathrm{Sb}\end{array}$ & $\begin{array}{c}\mathrm{CoSb}_{3}+ \\
+\mathrm{Sb}\end{array}$ & $\begin{array}{c}\mathrm{CoSb}_{3}+ \\
+\mathrm{Sb}\end{array}$ \\
\hline 400 & & & & & $\mathrm{CoSb}_{3}$ & $\begin{array}{c}\mathrm{CoSb}_{3}+ \\
+\mathrm{Sb}\end{array}$ & $\begin{array}{c}\mathrm{CoSb}_{3}+ \\
+\mathrm{Sb}\end{array}$ \\
\hline 450 & & & & & $\mathrm{CoSb}_{3}$ & $\begin{array}{c}\mathrm{CoSb}_{3}+ \\
+\mathrm{Sb}\end{array}$ & $\begin{array}{c}\mathrm{CoSb}_{3}+ \\
+\mathrm{Sb}\end{array}$ \\
\hline 600 & & & & $\begin{array}{l}\mathrm{CoSb}_{3}+ \\
+\mathrm{CoSb}_{2}\end{array}$ & & $\mathrm{CoSb}_{3}$ & $\begin{array}{c}\mathrm{CoSb}_{3}+ \\
+\mathrm{Sb}\end{array}$ \\
\hline 650 & & & & & $\begin{array}{l}\mathrm{CoSb}_{3}+ \\
+\mathrm{CoSb}_{2}\end{array}$ & & $\begin{array}{l}\mathrm{CoSb}_{3}+ \\
+\mathrm{CoSb}_{2}\end{array}$ \\
\hline
\end{tabular}

The annealing of $\mathrm{CoSb}_{x}$ crystal films (30 $\left.\mathrm{nm} ; 3.2<x<4.2\right)$ initially results to sublimation of excess $\mathrm{Sb}$, then chemical bonds in $\mathrm{CoSb}_{3}$ and $\mathrm{CoSb}_{2}$ antimonides are broken. One part of the released antimony atoms 

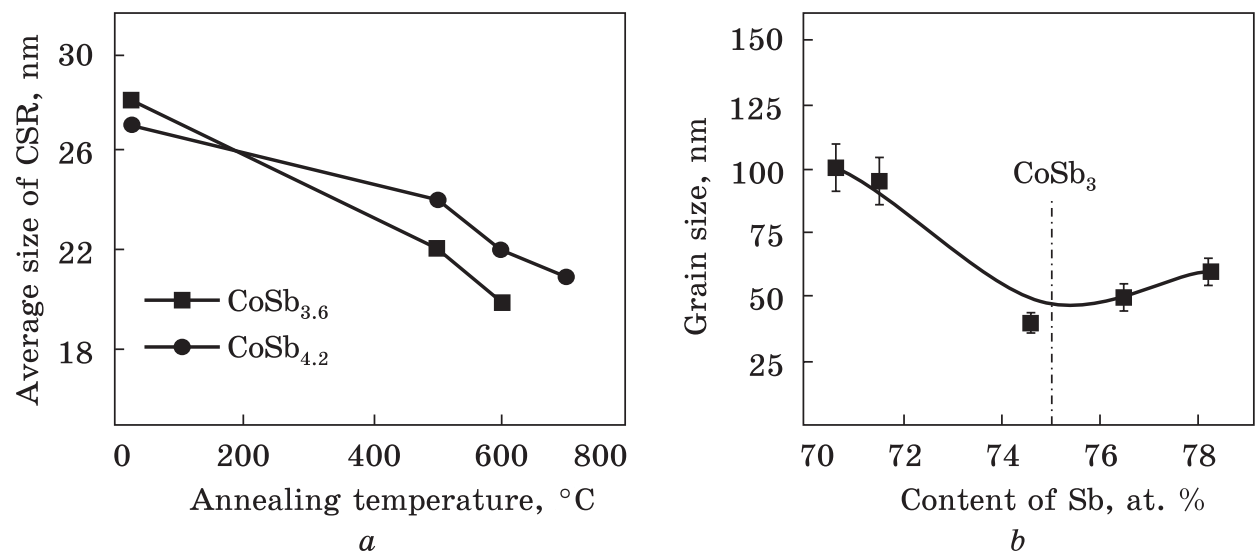

Fig. 14. The size dependences of $\mathrm{CoSb}_{3} \mathrm{CSR}$ phase on the annealing temperature in vacuum $(a)$ and Sb-concentration of grain after deposition at $T_{\mathrm{s}}=200{ }^{\circ} \mathrm{C}(b)$ in the Co-Sb films

forms $\mathrm{CoSb}_{2}$ or $\mathrm{CoSb}$ with a lower content of $\mathrm{Sb}$, while another part of diffusion-stimulated antimony accumulates atoms at the grain boundaries where then sublimes (Fig. 13).

In the crystalline films obtained from the X-ray amorphous state, the excess antimony initially goes out from the voids of the crystal lattice, and then sublimes. The generalized experimental data on the determination of the phase composition after annealing in vacuum are presented in Table 3.

An influence of phase transformations on the structure of films reflects in contraction of the sizes of grains and regions of coherent scattering with an increase of annealing temperature due to the sublimation of Sb (Fig. 14, a).

Furthermore, the structure imperfection rises: the extension of grain boundaries increases, nanosize voids appear. The grain size in the $\mathrm{CoSb}_{3}$ film is lower in comparison to the films with a two-phase composition (Fig. 14, b). This tendency continues even after annealing. These values are three times lower as compared with a material in the bulky condition [12]. Combination of such factors contributes to increase in a thermoelectric efficiency coefficient $(Z T)$ due to decrease in a thermal conductivity coefficient.

We revealed that a thermal stability of the $\mathrm{CoSb}_{3}$-based nanosize films is conserved up to $\approx 300{ }^{\circ} \mathrm{C}$, which is evidenced by the fact that the ratio of the most intense diffraction maxima for the $\mathrm{CoSb}_{3}$ and $\mathrm{Sb}$ phases remains unchanged during the long-time annealing (Fig. 15) [13, 14].

The rate of sublimation of antimony at different annealing temperatures above the $300{ }^{\circ} \mathrm{C}$ was used to estimate the activation energy $\left(E_{a}\right)$ of this process according to the Arrhenius equation. 


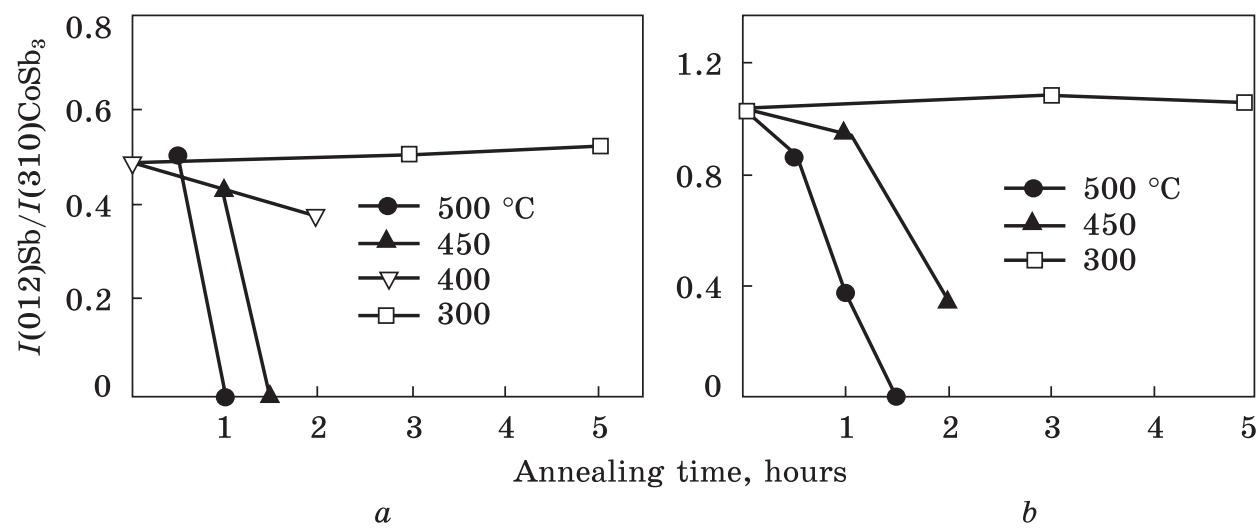

Fig. 15. Dependence of the intensity ratio of the $I(012) \mathrm{Sb} / I(310) \mathrm{CoSb}_{3}$ diffraction peaks for $\mathrm{CoSb}_{3.6}(a)$ and $\mathrm{CoSb}_{4.2}(b)$ films on the annealing time in vacuum within the temperature range of $300-500{ }^{\circ} \mathrm{C}$

Annealing of X-ray amorphous films leads to a more intense sublimation process than in case of crystalline films. This is reflected in the fact that the value of $E_{a}$ is 2-3 times smaller as compared to the films with a crystalline structure, where larger values of the energy are needed to break existing chemical bonds that have not yet formed insufficiently in the X-ray amorphous films (Fig. 16).

Thus, sublimation mechanisms depend on the structural state of the films. When the X-ray amorphous films undergo the annealing, antimony partially sublimes during the formation of the crystal lattice. When the crystalline films are annealed after breaking of chemical bonds, Sb initially diffuses to the grain boundaries, and then sublimates therefrom (Fig. 17, c).

The change in the phase composition of the films affects level of the stressed state. Calculated mechanical stresses in the films after their deposition and thermal annealing have different character and mecha-

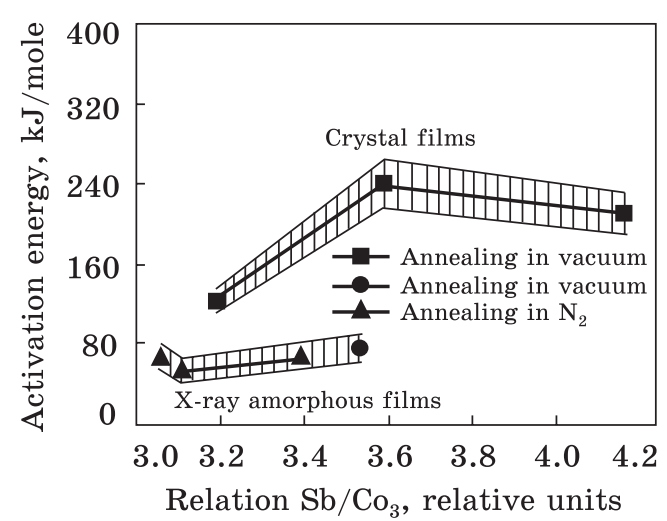

Fig. 16. Dependence of activation energy for $\mathrm{Sb}$ sublimation in $\mathrm{Co}-\mathrm{Sb}$ films nism. They emerge due to, firstly, mismatch of the temperature coefficient of linear expansion of $\mathrm{CoSb}_{3}$-based film $(\alpha=$ $\left.=8.8 \cdot 10^{-6} \mathrm{~K}^{-1}\right)$ and $\mathrm{SiO}_{2}(100 \mathrm{~nm}) /$ $\operatorname{Si}(001)$ substrate $\left(\alpha=2.6 \cdot 10^{-6} \mathrm{~K}^{-1}\right)$, and secondly, due to the phase transformations when Sb sublimates during thermal annealing. This leads to a decrease in the volume of the film during the sublimation of antimony and the formation of irreversible tensile stresses. 

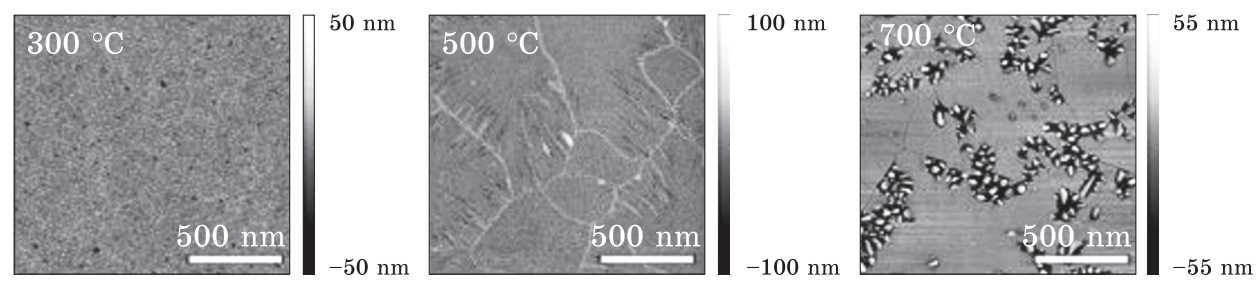

Fig. 17. Morphology of $\mathrm{CoSb}_{3.1}$ film after annealing in a nitrogen atmosphere during $30 \mathrm{~s}$ at $300{ }^{\circ} \mathrm{C}(a), 500{ }^{\circ} \mathrm{C}(b)$, and $700{ }^{\circ} \mathrm{C}(c)$

The change in residual stresses after deposition and after annealing, as the resultant two mechanisms of their formation, showed that the level of tensile mechanical stresses after annealing at a temperature of $500{ }^{\circ} \mathrm{C}$ increases by a factor of $\approx 5$ (Fig. 18). This is accompanied by a decrease in the size of the coherent scattering regions upon sublimation of $\mathrm{Sb}$ (Fig. 14, a) and leads to the appearance of cracks in the film and its further degradation (Fig. 17, b and $c$ ) [16].

The thermoelectrical efficiency coefficient $Z T$ for $\mathrm{CoSb}_{3.0}$ film is $\approx 1$ at $500{ }^{\circ} \mathrm{C}[9,10]$, this is $\approx 8$ times higher as compared with the material in a bulky state when $Z T \approx 0.12$ [12] (Fig. 19). $\mathrm{CoSb}_{4.1}$ film with excess of $\mathrm{Sb}$ has lower values of $Z T \approx 0.2$. The effect of increasing of thermoelectric efficiency coefficient is caused by the nanosize factor: the presence of single-phase crystal structure of $\mathrm{CoSb}_{3}$ scutterudite with an extended existence region $(75-80$ at. $\% \mathrm{Sb})$ in the film, and enhanced structural imperfection due to antimony sublimation-decrease in grain sizes and increase in extent of grain boundaries.

In further studies, to increase the $Z T$, we plan to dope of nanosize $\mathrm{Co}-\mathrm{Sb}$ films with dif-

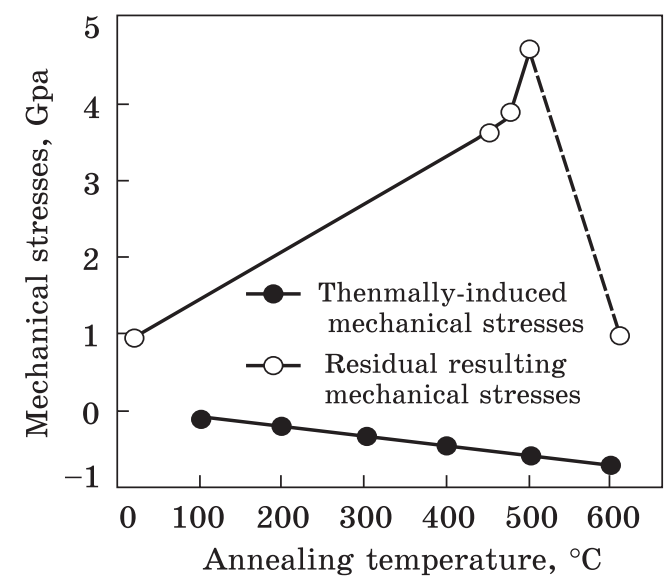

Fig. 18. Mechanical stresses vs. annealing temperature in $\mathrm{CoSb}_{3.6}$ film

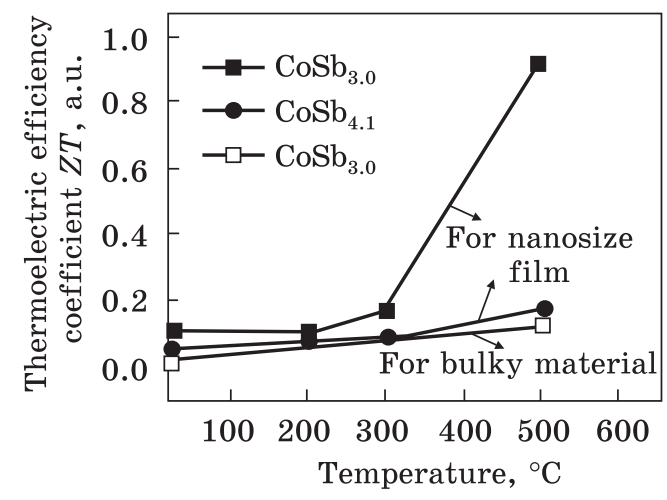

Fig. 19. Temperature-dependent thermoelectric efficiency coefficient in the $\mathrm{Co}-\mathrm{Sb}$ films 
ferent chemical elements $\mathrm{Fe}, \mathrm{Yb}, \mathrm{Li}, \mathrm{Eu}, \mathrm{La}, \mathrm{Ce}, \mathrm{Ba}$ to form a structure that can better conduct electric current (as a crystalline conductor) and poorly conduct a heat (like a glass). This will make possible to reduce a phonon component of the heat conductivity and much more increase thermoelectric efficiency coefficient $Z T$. Doping elements occupy voids in the crystal lattice-atomic polyhedrons of large sizes.

This provides an effective phonon scattering, which in turn results to decreasing of the heat conductivity without a substantial impact on electrical conductivity due to mainly ionic character of interaction between phonons and atoms of scutterudite carcass and covalently bonded carcass with a small probability of chemical bonds [16-19].

\section{Conclusions}

We used a complex of different methods of investigation in order to reveal the main laws of formation of phase composition and structure, to determine electrophysical properties of $\mathrm{Co}-\mathrm{Sb}$ nanosize films after deposition and annealing in vacuum and nitrogen atmosphere.

It is shown that deposition of Co-Sb films (with $65-81 \%$ of $\mathrm{Sb}$ ) on the substrates at a room temperature results to the formation of X-ray amorphous state of condensed material with an extended region for existence of the $\mathrm{CoSb}_{3}$ (75-80 at.\% Sb) phase at a further heating after crystallization. In case of a deposition of Co-Sb films (65-81 at.\% Sb) on the substrates at $200{ }^{\circ} \mathrm{C}$, the crystal state of condensed material forms in accordance with the phase equilibrium diagram for a bulky state of the $\mathrm{Co}-\mathrm{Sb}$ system.

The nanosize $\mathrm{CoSb}_{3}$ films are stable up to $\approx 300{ }^{\circ} \mathrm{C}$. Increase of the temperature of annealing in both vacuum and nitrogen atmosphere results to the sublimation of abundant antimony in the crystal or X-ray amorphous state and from $\mathrm{CoSb}_{2}$ and $\mathrm{CoSb}_{3}$ phases, which is reflected in the changing of phase composition and structure accordingly to the schemes as follows:

$$
\begin{gathered}
\mathrm{CoSb}_{3}+\mathrm{Sb} \stackrel{>300^{\circ} \mathrm{C}(\mathrm{Sb} \uparrow)}{\longrightarrow} \mathrm{CoSb}_{3} \stackrel{>400-500{ }^{\circ} \mathrm{C}(\mathrm{Sb} \uparrow)}{\longrightarrow} \mathrm{CoSb}_{3}+\mathrm{CoSb}_{2}, \\
\mathrm{CoSb}_{2} \stackrel{>500-600^{\circ} \mathrm{C}(\mathrm{Sb} \uparrow)}{\longrightarrow} \mathrm{CoSb}_{2}+\mathrm{CoSb} .
\end{gathered}
$$

We revealed that the process of Sb sublimation is much more intensive for annealing of $\mathrm{Co}-\mathrm{Sb} \mathrm{X}$-ray amorphous films. Activation energy for X-ray amorphous films being annealed in vacuum is $\approx 65 \mathrm{~kJ} / \mathrm{mole}$, which is $\approx 2-3$ times lower in comparison to the films with crystal composition.

As shown, after deposition of nanosize Co-Sb film (with abundant concentration of antimony), there are slight mechanical stresses $\approx 1 \mathrm{GPa}$. 
After the thermal annealing, these stresses increase up to $\approx 1 \mathrm{GPa}$, grain sizes decrease, cracks appear, and film material degrades.

There is a nanosize factor-a single-phase crystal structure of $\mathrm{CoSb}_{3}$ scutterudite with extended existence region $(75-80$ at.\% $\mathrm{Sb})$ in the film with high structural defectiveness due to nanosize grains that decrease as annealing temperature increases during antimony sublimation. This nanosize effect causes increase in thermoelectric efficiency coefficient at $500{ }^{\circ} \mathrm{C}(Z T \approx 1)$ as compared with that for material in a bulky state $(Z T \approx 0.12)$.

Acknowledgements. The authors are grateful to colleagues from Department of Surface and Interface Physics at Institute of Physics of Technische Universität Chemnitz (Germany), particularly head of the department Prof. M. Albrecht, Drs. M. Daniel and G. Beddies for the fabrication of samples, help during the investigations, and discussing the results. This work was financially supported by the German scientific exchange organization (DAAD) within the framework of the Euler program (grants No. 08/01145 and No. 50744282).

\section{REFERENCES}

1. A.F. Ioffe, Ehnergeticheskie Osnovy Termoelektricheskikh Batarey iz Poluprovodnikov [Energy Basis of Thermoelectric Semiconductor Batteries] (MoscowLeningrad: AN SSSR.: 1950) (in Russian).

2. A.O. Epreman, V.M. Arutyunyan, and A.I. Vaganyan, Alternative Energy and Ecology (ISJAEE), 25, No. 5: 7 (2005) (in Russian).

3. A.V. Shevelkov, Russ. Chem. Rev., 77, No. 1: 1 (2008).

4. M. Carle, P. Pierrat, C. Lahalle-Gravier, S. Scherrer, and H. Scherrer, J. Phys. Chem. Solids, 56: 201 (1995).

5. G.A. Slack, New Materials and Performance Limits for Thermoelectric Cooling, CRC Handbook of Thermoelectrics (Ed. D.M. Rowe) (Boca Raton: CRC Press: 1995), p. 407.

6. D.M. Freik, M.O. Galuschak, O.S. Krunutcky, and O.M. Matkivskiy, Physics and Chemistry of Solid State, 14, No. 2: 300 (2013) (in Ukrainian).

7. X.J. Zheng, L. Zhu, and Y.-H. Zhou, Applied Phys. Lett., 87: 242101 (2005).

8. J. Sommerlatte, K. Nielsch, and H. Bottner, Physik Journal, 6, Nr. 5: 35 (2007) (in German).

9. D. Zhao, Ch. Tian, Y. Liu, Ch. Zhan, and L. Chen, J. Alloys and Compounds, 509: 3166 (2011).

10. Yu.N. Makogon, E. P. Pavlova, S.I. Sidorenko, D. Beke, A. Csik, and R.A. Shkarban, Metallofiz. Noveishie Tekhnol., 36, No. 12: 1621 (2014) (in Russian).

11. Yu. M. Makogon, S. I. Sidorenko, and R. A. Shkarban, Metallofiz. Noveishie Tekhnol., 39, No. 5: 677 (2017) (in Russian).

12. Yu.N. Makogon, S.I. Sidorenko, and R.A. Shkarban, Metaloznavstvo ta Obrobka Metaliv, No. 1 (77): 39 (2016) (in Ukrainian). 
13. M.V. Daniel, C. Brombacher, G. Beddies, N. Jöhrmann, M. Hietschold, D.C. Johnson, Z. Aabdin, N. Peranio, O. Eibl, and M. Albrecht, J. Alloys and Compounds, 624: 216 (2015).

14. M.V. Daniel, L. Hammerschmidt, C. Schmidt, F. Timmermann, J. Franke, N. Jöhrmann, M. Hietschold, D.C. Johnson, B. Paulus, and M. Albrecht, Phys. Rev. B, 91: 085410 (2015).

15. C. Caylor, A.M. Stacy, B. Bloom, R. Gronsky, T. Sands, W.W. Fuller-Mora, A. Ehrlich, D. Song, and G. Chen, IEEE 18th International Conference on Thermoelectrics (August 29-September 2, 1999), p. 657.

16. N.R. Dilley, E.D. Bauer, M.B. Maple, S. Dordevic, D.N. Basov, F. Freibert, T.W. Darling, A. Migliori, B.C. Chakoumakos, and B.C. Sales, Phys. Rev. B, 61, No. 7: 4608 (2000).

17. G.A. Lamberton Jr., S. Bhattacharya, R.T. Littleton IV, M.A. Kaeser, R.H. Tedstrom, and T.M. Tritt, Appl. Phys. Lett., 80, No. 4: 598 (2002).

18. J.Y. Peng, P.N. Alboni, J. He, B. Zhang, Z. Su, T. Holgate, N. Gothard, and T.M. Tritt, J. Appl. Phys., 104: 053710 (2008).

19. A. Harnwunggmounga, K. Kurosakia, Y. Ohishia, H. Muta, and Sh. Yamanaka, J. Alloys and Compounds, 509: 1084 (2011).

Received November 7, 2017;

in final version, March 12, 2018

Ю.М. Макогон, С.І. Сидоренко, Р.А. Шкарбань

Національний технічний університет України

«Київський політехнічний інститут імені Ігоря Сікорського»,

просп. Перемоги, 37, 03056 Київ, Україна

\section{ВИГОТОВЛЕННЯ НАНОРОЗМІРНИХ ПЛІВОК \\ НА ОСНОВІ СКУТЕРУДИТУ $\mathrm{CoSb}_{3}$ ДЛЯ ТЕРМОЕЛЕКТРИЧНИХ ПРИЛАДІВ}

Роботу присвячено встановленню закономірностей термостимульованого формування фазового складу та структури плівок на основі скутерудиту $\mathrm{CoSb}_{3}$, осаджених методом вакуумної конденсації, а також впливу чинника нанорозмірности на їхні термоелектричні властивості. Вивчено вплив температури підкладинки та фізико-технологічних параметрів (температура, тривалість, середовище) термічного оброблення на фазовий склад, структуру, рівень механічних напружень і термоелектричні властивості плівок $\operatorname{CoSb}_{x}$ товщиною у 30 нм $(1,8 \leq x \leq 4,2$; 65-81 ат.\% Sb). Визначено, що зміна температури підкладинки при осадженні нанорозмірних плівок Co-Sb у концентраційному інтервалі 65-81 ат.\% Sb уможливлює регулювати структурний стан. При осадженні на підкладинки за кімнатної температури формується рентгеноаморфний стан з розширеною областю існування фази $\mathrm{CoSb}_{3}$ 75-80 ат.\% $\mathrm{Sb}$ після кристалізації при подальшому нагріванні. При збільшенні температури підкладинки до $200{ }^{\circ} \mathrm{C}$ утворюється кристалічний стан, і закономірності формування фазового складу в плівках Co-Sb xaрактеризуються послідовністю, яка аналогічна діяграмі фазової рівноваги станів для масивної системи $\mathrm{Co}-\mathrm{Sb}$ з утворенням фази $\mathrm{CoSb}_{3}$ при $\approx 75$ ат.\% $\mathrm{Sb}$. Встановлено, що плівки на основі $\mathrm{CoSb}_{3}$ термічно стабільні до $\approx 300{ }^{\circ} \mathrm{C}$. Термічне оброблення плівок $\mathrm{Co}-\mathrm{Sb}$ з концентрацією $\mathrm{Sb} 65-81$ ат.\% як у вакуумі, так і в атмосфері азоту при температурах вище $300^{\circ} \mathrm{C}$ приводить до перебігу фазових 
перетворень і зміни структури за схемами: $\mathrm{CoSb}_{3}+\mathrm{Sb} \rightarrow \mathrm{CoSb}_{3}$ (при $300{ }^{\circ} \mathrm{C}$ ), $\mathrm{CoSb}_{3} \rightarrow \mathrm{CoSb}_{3}+\mathrm{CoSb}_{2}$ (при 400-500 ${ }^{\circ} \mathrm{C}$ ), $\mathrm{CoSb}_{2} \rightarrow \mathrm{CoSb}_{2}+\mathrm{CoSb}$ (при 500-600 ${ }^{\circ} \mathrm{C}$ ) внаслідок зростаючої зі збільшенням температури відпалювання здатности атомів $\mathrm{Sb}$ до сублімації як з рентґеноаморфного або кристалічного станів, так і 3 антимонідів кобальту $\mathrm{CoSb}_{2}$ і $\mathrm{CoSb}_{3}$. Визначено, що наявність чинника нанорозмірности (однофазної кристалічної структури скутерудиту $\mathrm{CoSb}_{3}$ з розширеною областю існування в плівці з підвищеною структурною дефектністю за рахунок сублімації сурми і зменшення розміру зерен) зумовлює підвищення коефіцієнта термоелектричної ефективности плівок $\mathrm{Co}-\mathrm{Sb}$ у $\approx 8$ разів у порівнянні з масивним матеріялом. Це має практичну значимість при використанні цих матеріялів для забезпечення автономним живленням малопотужних електронних пристроїв і при створенні плівкових холодильників в елементній базі нанорозмірного діяпазону для комп'ютерної техніки та інфрачервоних давачів.

Ключові слова: нанорозмірна плівка, термічне оброблення, скутерудит $\mathrm{CoSb}_{3}$, антимонід, коефіцієнт термоелектричної ефективности.

\section{Ю.М. Макогон, С.И. Сидоренко, Р.А. Шкарбань}

Национальный технический университет Украины

«Киевский политехнический институт имени Игоря Сикорского», просп. Победы, 37, 03056 Киев, Украина

\section{ИЗГОТОВЛЕНИЕ НАНОРАЗМЕРНЫХ ПЛЕНОК НА ОСНОВЕ СКУТТЕРУДИТА $\mathrm{CoSb}_{3}$ ДЛЯ ТЕРМОЭЛЕКТРИЧЕСКИХ ПРИБОРОВ}

Работа посвящена установлению закономерностей термостимулированного формирования фазового состава и структуры пленок на основе скуттерудита $\mathrm{CoSb}_{3}$, осаждённых методом вакуумной конденсации, а также влияния фактора наноразмерности на их термоэлектрические свойства. Изучено влияние температуры подложки и физико-технологических параметров (температура, продолжительность, среда) термической обработки на фазовый состав, структуру, уровень механических напряжений и термоэлектрические свойства пленок $\mathrm{CoSb}_{x}$ толщиной 30 нм $(1,8 \leq x \leq 4,2 ; 65-81$ ат.\% Sb). Определено, что изменение температуры подложки при осаждении наноразмерных плёнок $\mathrm{Co}-\mathrm{Sb}$ в концентрационном интервале 65-81 ат.\% Sb позволяет регулировать структурное состояние. При осаждении на подложки при комнатной температуре формируется рентгеноаморфное состояние с расширенной областью существования фазы $\mathrm{CoSb}_{3} 75-80$ ат.\% $\mathrm{Sb}$ после кристаллизации при дальнейшем нагреве. При увеличении температуры подложки до $200^{\circ} \mathrm{C}$ образуется кристаллическое состояние, и закономерности формирования фазового состава в пленках $\mathrm{Co}-\mathrm{Sb}$ характеризуются последовательностью, которая аналогична диаграмме фазового равновесия состояний для массивной системы Сo-Sb с образованием фазы $\mathrm{CoSb}_{3}$ при $\approx 75$ aт.\% $\mathrm{Sb}$. Установлено, что пленки на основе $\mathrm{CoSb}_{3}$ термически стабильны до $\approx 300{ }^{\circ} \mathrm{C}$. Термическая обработка пленок $\mathrm{Co}-\mathrm{Sb}$ с концентрацией $\mathrm{Sb} 65-81$ ат.\% как в вакууме, так и в атмосфере азота при температурах выше $300^{\circ} \mathrm{C}$ приводит к протеканию фазовых превращений и изменению структуры по схемам: $\mathrm{CoSb}_{3}+\mathrm{Sb} \rightarrow$ $\rightarrow \mathrm{CoSb}_{3}$ (при $300{ }^{\circ} \mathrm{C}$ ), $\mathrm{CoSb}_{3} \rightarrow \mathrm{CoSb}_{3}+\mathrm{CoSb}_{2}$ (при 400-500 ${ }^{\circ} \mathrm{C}$ ), $\mathrm{CoSb}_{2} \rightarrow \mathrm{CoSb}_{2}+$ $+\mathrm{CoSb}$ (при 500-600 ${ }^{\circ} \mathrm{C}$ ) вследствие растущей с увеличением температуры отжига способности атомов $\mathrm{Sb}$ к сублимации как с рентгеноаморфного или крис- 
таллического состояний, так и из антимонидов кобальта $\mathrm{CoSb}_{2}$ и $\mathrm{CoSb}_{3}$. Определено, что наличие фактора наноразмерности (однофазной кристаллической структуры скуттерудита $\mathrm{CoSb}_{3}$ с расширенной областью существования в плёнке с повышенной структурной дефектностью за счёт сублимации сурьмы и уменьшения размера зёрен) обуславливает повышение коэффициента термоэлектрической эффективности плёнок $\mathrm{Co}-\mathrm{Sb}$ в $\approx 8$ раз по сравнению с материалом в массивном состоянии. Это имеет практическую значимость при использовании этих материалов для обеспечения автономным питанием маломощных электронных устройств и при создании плёночных холодильников в элементной базе наноразмерного диапазона для компьютерной техники и инфракрасных датчиков.

Keywords: nanoscale film, heat treatment, $\mathrm{CoSb}_{3}$ scutterudite, antimonide, thermoelectric efficiency coefficient. 